\title{
MLL/MLLT4 Fusion Gene
}

National Cancer Institute

\section{Source}

National Cancer Institute. MLL/MLLT4 Fusion Gene. NCI Thesaurus. Code C99351.

A fusion gene that results from a chromosomal translocation $t(6 ; 11)(q 27 ; q 23)$ which fuses the 5 ' half of the MLL gene to most of the MLLT4 gene. This rearrangement is associated with acute myeloid leukemia. 